\title{
The Night of Baconaua
}

TRANSLATED BY JOEL DAVID

\section{Paul Alcoseba Castillo \\ University of Santo Tomas}

Joseph Israel Laban's Baconaua attempts a long journey over sea and darkness, as manifested in the crossing of boats across the frame amid the stillness of water, as well as the slow traversal of its characters. The separate observance of rituals for family members believed to have perished signals to us that the darkness of the night and sea is tantamount to death. Redolent of the burial ritual of precolonial Filipinos that made use of Manunggul jars, where the dead ancestor is transported to the afterlife by means of a boat ride. Nevertheless, the decision to darken the cinematography conveys the impression of a never-ending eclipse throughout the film. This is commonly associated with the mythological dragon, the bakunawa that supposedly devours the moon and causes it to vanish during a lunar eclipse. Two foreign versions of the Philippine national anthem are broadcasted over a transistor radio to indicate a new day but the camera reveals an image of several islands that disavows the hopefulness in the soundtrack when the sun refuses to cast any light on the earth.

Aside from the darkness, other attributes associated with the bakunawa's perception are manifested directly and implicitly. In this place, people believe that the creature abducted anyone brazen enough to plumb the ocean's depth or sail too far out, as in the instance of the disappearance of the father and the warnings sounded by children at the shore. For the residents of Marinduque, 
believing in the human-snatching monster has become part of their way of life although the film merely hints at this, possibly to retain its mystique. The bakunawa remains submerged so that it cannot be readily perceived, as what occurred in the accident of Dino (JM Salvado), the youngest and only son among the siblings. But the province's own monster is also equated with the dragon of the West and of the Chinese as depicted in the arrival of Chinese migrants.

On the other hand, the moon is constantly being consumed by such a monster, whose attacks, according to legend, used to return for six more months. The only reason that the seventh month could be saved was because the residents would create enough uproar to drive the bakunawa to its origin. And just like the archetypal correlation of women with the moon in various types of literature, the roles of Divina (Elora Españo) and Dian (Therese Malvar), the two eldest children orphaned of their father, may also be seen as moon-like in their character. This would be better manifested toward the end, during full moon, at the moment when the eldest is apparently by herself, the remaining child implicitly assuming the duties left by the departed mother, missing father, slain youngest, and wayward sibling. Even the last image illustrates the singularity of the gigantic moon above the sea as Divina floats toward it.

From a native perspective, one can sense the predominance of concepts derived from Christianity even in the consciousness of those outside the seat of power. The sudden arrival of untold numbers of apples at the beach forebodes misfortune for certain natives but is considered a gift by others. If we were to follow the depiction of artworks based on Genesis, the apple would be the fruit that caused Eve to sin and become enlightened, another woman who decided for both herself and Adam. But in this case, one may perceive that she has learned from her transgression a lesson that she insists on teaching her younger sibling who has fallen for the same man and has literally and figuratively tasted forbidden fruit.

The sea is more powerful than what the film depicts and should be feared more than the bakunawa because everyone's livelihood depends on the sea. This is where their daily sustenance is derived but it has also claimed 
their loved ones. This is where they perform their rituals and accept the loss of those who perished even as it sets apart parents from offspring. This is where bounty and wealth can be derived although threats from outside also arrive through it. The sea of Baconaua must be recognized as a character capable of not only giving but also taking in order to restore the balance of nature. 


\section{Acknowledgment}

Reprinted with the author's permission from the Kung Sine Sine Lang blog, June 8, 2017, kungsinesinelang.wordpress.com/2017/08/06/ ang-gabi-ng-baconaua/. 